SŁAWOMIR TRUSZ

ORCID 0000-0002-7572-018X

Uniwersytet Pedagogiczny im. Komisji Edukacji Narodowej

$w$ Krakowie

\title{
CZY BADACZE JAKOŚCIOWI WIEDZĄ CO WIDZĄ, A OSOBY BADANE WIEDZĄ CO MÓWIĄ? O JAKOŚCI DANYCH JAKOŚCIOWYCH
}

ABSTRAct. Trusz Sławomir, Czy badacze jakościowi wiedza co widza, a osoby badane wiedza co mówią? O jakości danych jakościowych [Do Qualitative Researchers Know what They See and do the Subjects Know what They Say? On the Quality of Qualitative Data]. Studia Edukacyjne nr 56, 2020, Poznań 2020, pp. 199-219. Adam Mickiewicz University Press. ISSN 1233-6688. DOI: 10.14746/se.2020.56.11

Empirical data collected through qualitative methods may be more or less reliable and valid. The paper describes cognitive and social factors affecting credibility of information obtained by means of non-standardized observation and interview. The aforementioned issue was illustrated by the results of investigation on the change blindness and false memories phenomena. Finally, the procedures for improving the quality of qualitative data and, consequently, the reasonableness of conclusions regarding the analyzed social phenomena were discussed.

Key words: reliability, validity of qualitative data, non-standardized observation, qualitative interview

Podczas rekonstruowania zjawisk społecznych badacze jakościowi - socjolodzy, pedagodzy, psycholodzy - gromadzą dane empiryczne za pomocą specyficznych metod i strategii. Do najpopularniejszych można zaliczyć niestandaryzowaną obserwację uczestniczącą ${ }^{1}$ i wywiad jakościowy ${ }^{2}$. Obydwie te metody charakteryzują się dużą swobodą postępowania badawczego ${ }^{3}$.

${ }^{1}$ M. Lichtman, Qualitative research in education. A user's guide (2nd edition), London 2013; J. Lofland i in., Analiza układów społecznych. Przewodnik metodologiczny po badaniach jakościowych, Warszawa 2009.

${ }^{2}$ S. Kvale, InterViews. Wprowadzenie do jakościowego wywiadu badawczego, Białystok 2004; H.J. Rubin, I.S. Rubin, Qualitative interviewing. The art of hearing data (3rd edition), Los Angeles 2012.

${ }^{3}$ M. Hammersley, P. Atkinson, Metody badań terenowych, Poznań 2000. 
Zwracając uwagę na czynniki kontekstowe, na przykład nieoczekiwaną obecność osób trzecich, wyraźnie wpływającą na zachowania obserwowanych osób/respondentów, badacz może spontanicznie modyfikować procedury pozyskiwania informacji, na przykład rezygnując z wybranych kategorii zachowań lub tematów rozmowy na rzecz innych - adekwatnych z punktu widzenia stanu emocjonalnego i potrzeb uczestników badania. Innymi słowy, zwolennicy orientacji jakościowej w naukach społecznych, w przeciwieństwie do badaczy ilościowych, dopasowują zachowania do toczącej się, niczym na planie filmowym, akcji/przebiegu zdarzeńt.

Swoboda działań wynika po części z postulatu pełnienia roli „naiwnego współuczestnika analizowanych zdarzeń". Podejmując zadania charakterystyczne dla członków badanej społeczności, badacz jakościowy obserwuje i prowadzi rozmowy z partnerami interakcji, bez przyjmowania wstępnych założeń na temat charakteru analizowanych fenomenów ${ }^{5}$.

Korzystanie $\mathrm{z}$ niestandaryzowanych metod i strategii badań pozwala realizować właściwe dla orientacji rozumiejącej cele, to jest odkrywać znaczenia/sens nadawany przez ludzi osobistym doświadczeniom, a następnie - przedstawiać je za pomocą kategorii poznawczych i językowych charakterystycznych dla uczestników obserwacji/wywiadu. Clifford Geertz, wybitny antropolog kultury, podkreśla:

wierząc, że człowiek jest zwierzęciem zawieszonym w sieciach znaczeń, które sam utkał, pojmuję kulturę jako owe sieci, których analiza nie jest zatem nauką eksperymentalną, poszukującą praw, lecz nauką interpretatywną poszukującą znaczenia ${ }^{6}$.

Rzeczywiście, w przeciwieństwie do badań idiograficznych, w badaniach ilościowych (nomotetycznych) nacisk kładziony jest na odkrywanie obiektywnych - to jest niezależnych od badacza - prawidłowości. Badania eksperymentalne są organizowane według ściśle określonych scenariuszy, których przebieg podporządkowany jest testowanym relacjom przyczynowo-skutkowym ${ }^{7}$. Obowiązująca w nich reguła brzmi: „nieważny jest autor, lecz sposób realizacji badania". Ściśle opisany przebieg eksperymentu pozwala badanie powtórzyć, a rezultaty replikacji podsumować $\mathrm{w}$ metaanalizie (ilościowej syntezie wyników badań o podobnej tematyce i metodologii, na któ-

${ }^{4}$ J. Lofland i in., Analiza układów społecznych; K. Konecki, Studia z metodologii badań jakościowych: teoria ugruntowana, Warszawa 2000.

${ }^{5}$ K.T. Anderson-Levitt, Etnography, [w:] Handbook of complementary methods in education research, red. J.L. Green, G. Camilli, P.B. Elmore, Mahwah 2006, s. 279-295.

${ }^{6}$ C. Geertz, Opis gęsty - w strone interpretatywnej teorii kultury, [w:] Badanie kultury. Elementy teorii antropologicznej, red. M. Kempny, E. Nowicka, Kraków 2003, s. 36.

${ }^{7}$ J.M. Brzeziński, Badania eksperymentalne w psychologii i pedagogice, Warszawa 2008. 
rych podstawie szacowane są przeciętne wielkości efektu określonych czynników dla wybranych zmiennych wynikowych ${ }^{8}$.

\section{Zagadnienie rzetelności i trafności danych w badaniach ilościowych $v s$ jakościowych}

Kontrola błędu pomiaru oraz podejmowane próby jego minimalizowania powodują, że w badaniach ilościowych rzetelność wyników, a w konsekwencji - wiarygodność proponowanych wniosków jest wysoka. Z drugiej strony, wraz ze wzrostem precyzji pomiaru trafność ekologiczna uzyskiwanych rezultatów maleje. Oznacza to, że zachowania uczestników eksperymentów, skrupulatnie rejestrowane w sztucznych warunkach laboratorium, mogą nie być powtarzane w sytuacjach życia codziennego ${ }^{9}$. Na przykład, możliwie szybkie wciskanie wybranych przycisków klawiatury komputera w teście postaw ukrytych (IAT), mimo bezbłędnej kontroli czasów reakcji, często ma się nijak do rzeczywiście podejmowanych przez osoby badane decyzji związanych z udzielaniem pomocy innym lub przeciwnie - ich negatywnym traktowaniem ${ }^{10}$.

Zagadnienie rzetelności i trafności wyników pomiaru w badaniach ilościowych jest dobrze rozpoznane i przedyskutowane w literaturze fachowej ${ }^{11}$. Dla odmiany, w badaniach jakościowych celowa rezygnacja ze standaryzacji procedur badawczych i matematyzacji zmiennych, a w konsekwencji - nieilościowa, często niepowtarzalna natura gromadzonego materiału empirycznego, powoduje, że wskazana problematyka jest w dalszym ciągu źródłem licznych polemik i kontrowersji ${ }^{12}$.

Unikając, z podanych wcześniej powodów, interpretacji statystycznej, rzetelność analiz jakościowych, za Uwe Flickiem ${ }^{13}$, można zdefiniować jako precyzję tworzonych opisów, natomiast trafność - jako zasadność (sensow-

8 A.H. Schoenfeld, Design experiments, [w:] Handbook of complementary methods, s. 193-205; G.V. Glass, Meta-analysis: The quantitative synthesis of research findings, [w:] Tamże, s. 427-438.

9 P.G. Nestor, R.K. Schutt, Research methods in psychology. Investigating human behavior, Los Angeles 2012.

${ }_{10} \mathrm{~W}$. Hofmann $\mathrm{i}$ in., A meta-analysis on the correlation between the Implicit Association Test and explicit self-report measures, Personality and Social Psychology Bulletin, 2005, 31, s. 1369-1385.

11 J. Brzeziński, Metodologia badań psychologicznych, Warszawa 2012; B.L. Weathington, C.J. Cunningham, D.J. Pittenger, Research methods for the behavioral and social sciences, New Jersey 2010.

12 J. Kirk, M.L. Miller, Reliability and validity in qualitative research, Newbury Park 1986; M. Baumgarten, Paradigm wars - validity and reliability in qualitative research, Auflage 2010.

13 U. Flick, Jakość w badaniach jakościowych, Warszawa 2011. 
ność) proponowanych przez badacza interpretacji/wniosków. Wspólnie, trafność i rzetelność analiz decydują o jakości badań jakościowych.

W tym świetle za nierzetelne (nieprecyzyjne) należałoby uznać opisy zachowań grupy licealistów, z których wynika, że jedynym nastolatkiem pijącym alkohol był Daniel, mimo że wszyscy objęci obserwacją chłopcy, w trakcie imprezy szkolnej, konsumowali piwo. Podobnie, za nierzetelne można uznać transkrypcje wywiadów, w których pominięto wybrane frazy, na przykład wypowiedzi respondentów świadczące o ich negatywnej postawie wobec mniejszości etnicznych lub seksualnych. Z kolei, za nietrafne (bezzasadne) należałoby uznać interpretacje, zgodnie z którymi picie alkoholu na imprezach szkolnych jest zjawiskiem marginalnym, dotyczącym wyłącznie uczniów pochodzących z rodzin robotniczych, których przedstawicielem jest Daniel. Za podobnie nietrafną można uznać analizę, z której wynika, że uczestnicy wywiadu to $\mathrm{w}$ większości osoby tolerancyjne i otwarte na różne odmienności. Rzeczywiście, realizowane w ten sposób badania jakościowe charakteryzowałyby się wątpliwą jakością.

Biorąc pod uwagę podane definicje rzetelności i trafności analiz jakościowych, warto wskazać i przedyskutować istotne ograniczenia materiału empirycznego gromadzonego za pomocą podstawowych metod/strategii badań idiograficznych, to jest niestandaryzowanej obserwacji uczestniczącej i wywiadu swobodnego. W dużej mierze wynikają one z właściwych ludziom ograniczeń poznawczych i osobowościowych, co sprawia, że mają one charakter uniwersalny. Warto, aby badacze, $\mathrm{w}$ trakcie dyskutowania uzyskanych wyników, zdawali sobie sprawę z ich potencjalnego wpływu.

\section{Czy badacze jakościowi wiedzą, co mówią? Zjawisko ślepoty okołozmianowej}

Wspomniane ograniczenia warto zilustrować rezultatami intrygujących eksperymentów Daniela Simonsa i współpracowników ${ }^{14}$ na temat zjawiska ślepoty okołozmianowej. Dowodząc jego obezwładniającej siły, autorzy opublikowali w Sieci materiały pochodzące z badań.

W pierwszym nagraniu (https:/ / youtu.be/vJG698U2Mvo) grupa studentów ubranych w białe lub czarne podkoszulki podaje sobie piłkę. Zadaniem osoby oglądającej nagranie (nieuprzedzonego obserwatora) jest ustalenie liczby podań wykonanych przez studentów ubranych w białe podkoszulki. W trakcie nagrania przez środek korytarza przechodzi osoba ubrana w strój

\footnotetext{
${ }^{14}$ C. Chabris, D. Simons, Niewidzialny goryl. Dlaczego intuicja nas zawodzi?, Warszawa 2011.
} 
goryla. „Goryl” zatrzymuje się wśród osób wymieniających podania i ostentacyjnie uderza pięściami w klatkę piersiową. Około 50\% obserwatorów nie zauważa goryla, koncentrując uwagę na liczeniu podań wykonywanych przez osoby ubrane w białe podkoszulki.

W drugim nagraniu (https://youtu.be/1nL5ulsWMYc) zadaniem obserwatora jest ustalenie, który element przedstawionej $\mathrm{w}$ filmie sceny zmienia się. Większość osób podczas pierwszego odtworzenia filmu nie jest w stanie wskazać żadnej, nawet najdrobniejszej zmiany. W rzeczywistości zmiana występuje - w lewym górnym rogu ekranu powoli, sekunda po sekundzie, z tła wyłania się kamień. Podczas drugiego odtworzenia, miejsce, w którym pojawia się zmiana, udaje się zidentyfikować większości obserwatorów - być może dlatego, że w powtórce kamień migocze.

Rzeczywiście, ludziom olbrzymią trudność sprawia rejestrowanie zmian stopniowych, a nie gwałtowanych. Dobrym przykładem jest długotrwały proces utraty masy ciała - na przykład $10 \mathrm{~kg}$ w jednym roku. Zmian mogą nie dostrzegać osoby, którym udało się zrzucić niepotrzebne kilogramy. Ta sama zmiana zostanie jednak natychmiast zauważona, jeśli obserwator nie miał kontaktu z osobą przez rok i oceniona jako wyrazista, a nie stopniowa.

W trzecim nagraniu (https://youtu.be/FWSxSQsspiQ) pewien mężczyzna - pomocnik eksperymentatora odgrywający rolę turysty - podchodzi na ulicy do losowo wybranego przechodnia i prosi o wskazanie na planie miasta odpowiedniego kierunku trasy. Przechodzień kontaktuje się wzrokowo $\mathrm{z}$,turystą", wymienia z nim kilka zdań, patrzy na plan miasta, po raz kolejny kontaktuje się wzrokowo z "turystą" i wyjaśnia, jak dotrzeć do wskazanego wcześniej miejsca.

W tym czasie do rozmawiających mężczyzn podchodzą jednocześnie trzy osoby niosące drzwi. Kiedy drzwi przesłaniają "turystę" jedna z osób oddaje pomocnikowi eksperymentatora drzwi, po czym przejmując jego rolę, kontynuuje rozmowę z przechodniem. Co zaskakujące, przechodzień nie dostrzega zmiany - jest przekonany, że nadal rozmawia z tą samą osobą. Okazuje się, że około 50\% przechodniów ulega zjawisku ślepoty okołozmianowej - mimo wcześniejszego kontaktu wzrokowego i rozmowy z "turystą", nie dostrzega jego zmiany.

W ostatnim - niemniej intrygującym - nagraniu (https://youtu.be/ubNF9QNEQLA) zadaniem obserwatora jest rejestrowanie zmian planu filmowego, zachodzących w trakcie projekcji filmu. Zwracając uwagę na zachowania aktorów - osób podejrzanych o zabójstwo Lorda Smithe i prowadzącego śledztwo detektywa, obserwatorzy średnio identyfikują do pięciu zmian. W rzeczywistości jest ich 21 - modyfikacji ulegają właściwie wszystkie elementy kadru, nawet zwłoki Lorda Smithe. 


\section{Konsekwencje ograniczeń obserwacji niestandaryzowanej}

\section{Pomijanie danych istotnych}

Biorąc pod uwagę rezultaty eksperymentów Daniela Simonsa i współpracowników, warto zapytać: czy obserwacja niestandaryzowana (swobodna, pozbawiona planu, innymi słowy - wstępnych przedzałożeń na temat jej przebiegu i rejestrowanych treści) jest możliwa? Zapewne tak, ale należy pamiętać o konsekwencjach, to jest pomijaniu masy danych istotnych z punktu widzenia analizowanej problematyki, a w efekcie - obniżaniu rzetelności i trafności analiz jakościowych oraz proponowanych wniosków.

Obserwator bez trudu może udzielić odpowiedzi na pytanie: czy w nagraniu 1., w trakcie odbijania piłek przez studentów, środkiem korytarza przechodzi człowiek przebrany za goryla? albo czy w nagraniu 4., w trakcie przesłuchiwania podejrzanych, inspektor był ubrany w jasny czy raczej ciemny prochowiec? o ile wie, na jakie szczegóły filmu powinien zwrócić uwagę. Innymi słowy, jest to możliwe, jeżeli ma on pewne przedzałożenia dotyczące przedmiotu/treści obserwacji.

Podobnie $\mathrm{w}$ przypadku nagrania 2., pozbawiona celu obserwacja nie pozwala rejestrować zmian stopniowych, typowych dla analizowanych w naukach społecznych procesów, na przykład rozwojowych. Wynika z tego, że tylko obserwacja zaplanowana - o ustalonym celu i przebiegu - pozwala zwracać uwagę na te elementy zmieniającej się rzeczywistości, które świadczą o zmianie w ramach badanego procesu ${ }^{15}$.

\section{Generowanie pseudodanych}

Ponadto, brak planu obserwacji, wynikającego z przyjętych celów lub problematyki badawczej, może skłaniać obserwatorów do twórczego konstruowania nieistniejących faktów, tak zwanych pseudodanych ${ }^{16}$. Ich źródłem są schematy poznawcze, na przykład stereotypy społeczne, skrypty/scenariusze zdarzeń i schematy cech, posiadane przez badacza ${ }^{17}$.

Badania pokazują, że po zaktywizowaniu schematu poznawczego, na przykład agresywnego Murzyna, przebiegłego Żyda, przemądrzałego okularnika i tym podobnych, obserwatorzy są wyczuleni na informacje zgodne z wcześniej wzbudzonym stereotypem ${ }^{18}$. Co więcej, zdarza się, że w rzeczywi-

${ }^{15}$ C. Chabris, D. Simons, Niewidzialny goryl.

${ }^{16}$ B. Wojciszke, Dane i pseudodane w procesie spostrzegania ludzi, [w:] Złudzenia, które pozwalają żý́, red. M. Kofta, T. Szutrowa, Warszawa 2009, s. 65-90.

${ }_{17}$ S.L. Nauberg, Proces potwierdzania oczekiwań w interakcjach obciażonych stereotypami, [w:] Efekty oczekiwań interpersonalnych. Wybór tekstów, red. S. Trusz, Warszawa 2013, s. 555-579; J.M. Darley, R.H. Fazio, Proces potwierdzania oczekiwań w sekwencji interakcji społecznych, [w:] Tamże, s. 359-379.

${ }^{18}$ S.T. Fiske, S.E. Taylor, Social cognition. From brain to culture, Boston 2009. 
stości neutralne zachowania jednostek są rejestrowane, zapamiętywane, a następnie - interpretowane zgodnie z posiadanym schematem poznawczym ${ }^{19}$.

\section{Wywiad niestandaryzowany - ograniczenia i konsekwencje stosowania metody}

Korzystając z wywiadu niekierowanego ${ }^{20}$, badacz na bieżąco, to jest w trakcie prowadzonej rozmowy, ustala tematy i z dużą swobodą zadaje respondentom szczegółowe pytania. Podejmowane wątki powinny jednak wynikać z wcześniej przyjętych celów lub problematyki badawczej. Nie da się prowadzić sensownych rozmów z partnerami interakcji bez choćby wstępnego zarysowania głównego tematu wywiadu. Stąd, mimo olbrzymiej swobody w wyborze tematów i zadawanych respondentom mniej lub bardziej szczegółowych pytań, można mówić o tak zwanej ukrytej strukturze wywiadu lub planie wywiadu ukrytym w głowie badacza.

Niektórzy autorzy przekonują, że

wywiad swobodny także ma strukturę, ale określoną na poziomie abstrakcyjnym (teoretycznym i/lub metodologicznym), a nie konkretnym (pytań i odpowiedzi, bezpośrednio stosowanych w rozmowie). Określanie go mianem „wywiadu nieustrukturalizowanego", choć spotykane w literaturze, należy zatem uznać za mylące ${ }^{21}$.

Jeżeli zatem badacz

nie ma żadnego planu wywiadu i prowadzi rozmowę "podążając za osobą badaną" bez celu czy zamysłu, jeśli jego pytania wynikają z tego, co mu akurat przyszło na myśl, a po zakończeniu rozmowy nie wie, co z uzyskanymi danymi zrobić i opiera wnioski na tym, co zrobiło na nim szczególne wrażenie w rozmowie albo na tym, co z niej zapamiętał - to jest to właśnie wywiad prawdziwie nieustrukturalizowany. Może on być bardzo miłym przeżyciem dla obu stron (...) można cieszyć się taką rozmową na różne sposoby i zapewne odnieść z niej różnego rodzaju pożytki, prócz jednego - pożytku badawczego ${ }^{22}$.

Wynika z tego, że wywiad pozbawiony struktury i planu (bezzałożeniowy) jest błędem w sztuce. Skrajna swoboda procedur badawczych może przekształcać wywiad w niezobowiązującą rozmowę badacza z respondentami $\mathrm{o}$ „wszystkim i niczym”. W skrajnym przypadku konwersacja może przypo-

\footnotetext{
19 Tamże.

20 S. Kvale, Prowadzenie wywiadów, Warszawa 2010.

${ }^{21}$ K. Stemplewska-Żakowicz, Metoda wywiadu w psychologii, [w:] Wywiad psychologiczny, tom 1 - Wywiad jako postępowanie badawcze, red. K. Stemplewska-Żakowicz, K. Krejtz, Warszawa

${ }^{22}$ Tamże, s. 55.
} 2009, s. 55. 
minać kierowaną przez osoby badane grę wolnych skojarzeń - towarzyską wymianę zdań rzekomo zaprzyjaźnionych osób przy kawie lub ciastku, a nie rozmowę dobrze przygotowanego badacza $z$ wyselekcjonowanymi respondentami, zgodną z przyjętym celem lub problematyką badań.

Ponadto, kiedy badacz celowo rezygnuje z kierowania wywiadem, kierunek rozmowie mogą narzucać respondenci, zgodnie z własnymi potrzebami lub celami autoprezentacji (,zobacz badaczu, jaki jestem mądry, zadowolony z życia, biedny, nieszczęśliwy itp.") lub innymi, mniej lub bardziej jasnymi dla osób badanych - a tym bardziej badacza - motywami. Podsumowując, programowo zakładany brak kontroli nad przebiegiem rozmowy może przekształcać wywiad w karykaturę naukowej metody badań ${ }^{23}$.

Niezależnie od rodzaju prowadzonych badań - ilościowych lub jakościowych - badacza obowiązuje uniwersalna reguła GIGO (garbage in, garbage out - śmieci na wejściu, śmieci na wyjściu ${ }^{24}$ ). Korzystając z niskiej jakości danych, na przykład gromadzonych $\mathrm{w}$ trakcie pozbawionych struktury rozmów (śmieci na wejściu), badacz, chcąc nie chcąc, musi formułować niewiele warte wnioski na temat analizowanych zjawisk (śmieci na wyjściu). Krótko mówiąc, ukryty w głowie badacza plan rozmowy jest polecany także w przypadku wywiadu jakościowego.

\section{Wątpliwa jakość danych pochodzących z wywiadu. Czy osoby badane wiedzą, co mówią?}

Podstawowym źródłem danych gromadzonych w wywiadach są deklaracje osób badanych ${ }^{25}$. Rozmówcy mogą odpowiadać na pytania szczerze lub świadomie/nieświadomie mijać się z prawdą. Wynika z tego, że rzetelność i trafność danych pochodzących z wywiadu może być niższa aniżeli informacji gromadzonych za pomocą obserwacji (por. ryc. 1).

Wraz ze wzrostem liczby ścieżek (pośredników) informacja może przekształcać się w plotkę, tracąc na wiarygodności. Badacz korzystający z wywiadu nie dociera do faktów (danych naocznych), ale raczej do ich subiektywnych interpretacji, podawanych przez mniej lub bardziej wiarygodnych informatorów.

Należy wyraźnie podkreślić, że deklaracje na temat zachowań nie są tożsame z zachowaniami rzeczywiście prezentowanymi. Na przykład, osoby spektakularnie otyłe mogą deklarować dbałość o masę ciała, jednocześnie

\footnotetext{
${ }^{23}$ D. Doliński, Psychologia wptywu społecznego, Warszawa 2008.

${ }^{24}$ R. Dunbar, Kłopoty z nauka. Warszawa 1996.

25 A.N. Oppenheim, Kwestionariusze, wywiady, pomiary postaw, Warszawa 2004.
} 
1. Dane gromadzone w ramach obserwacji (zerowa liczba pośredników)

ZACHOWANIE/ZDARZENIE (Z/Z) $\leftarrow$ obserwacja: badacz widzi Z/Z

Np. Basia uderza Zenka w głowę $\leftarrow$ obserwacja: badacz widzi, że Basia uderza Zenka w głowę

2. Dane gromadzone w ramach wywiadu (1., 2., $n$ pośredników)

ZACHOWANIE/ZDARZENIE (Z/Z) $\leftarrow$ obserwacja: ktoś (informator) widzi Z/Z $\leftarrow$ wywiad: badacz słyszy od informatora, że Z/Z wystąpiło

Np. Basia uderza Zenka w głowę $\leftarrow$ obserwacja: ktoś (informator) widzi, że Basia uderza Zenka w głowę $\leftarrow$ wywiad: badacz dowiaduje się od informatora, że „Basia bije Zenka” (informator wiarygodny)

a nawet:

ZACHOWANIE/ZDARZENIE (Z/Z) $\leftarrow$ obserwacja: ktoś (informator 1.) widzi Z/Z $\leftarrow$ opowieść: informator 1. opowiada komuś (informator 2., 3., $n$-ty) o $Z / Z \leftarrow$ wywiad: badacz dowiaduje się od informatora 2., 3., $n$-tego, że Z/Z wystąpiło

Np. Basia uderza Zenka w głowę $\leftarrow$ obserwacja: ktoś (informator 1.) widzi, że Basia uderza Zenka w głowę $\leftarrow$ opowieść: informator 1. opowiada komuś (informator 2., 3., n-ty), że „Basia uderzyła Zenka w głowę" (informator wiarygodny) $\leftarrow$ wywiad: badacz dowiaduje się od informatora 2., 3., $n$-tego, że „ktoś powiedział, że Basia bije Zenka” lub „Zenek bije Basię” (informator 2., 3., $n$-ty niewiarygodny)

Ryc. 1. Ocena wiarygodności danych empirycznych gromadzonych w ramach badań obserwacyjnych i sondażowych

wpychając do ust kolejnego hamburgera. Podobnie członkowie organizacji neonazistowskich mogą deklarować pozytywną postawę wobec mniejszości narodowych, rasowych, seksualnych i tym podobnych, podpalając w tym samym czasie tęczę na Placu Zbawiciela w Warszawie i skandując hasła propagujące przemoc wobec "odmieńców”.

Okazuje się, że ludzie często co innego mówią na temat posiadanych przekonań i preferencji, a następnie, tuż po zakończeniu badania (np. wywiadu), co innego robią ${ }^{26}$. Opisaną niekonsekwencję dobrze ilustrują rezultaty eksperymentu przeprowadzonego przez autora artykułu, w którym oceniono związek między deklarowaną gotowością do bezinteresownego niesienia pomocy a pomocą rzeczywiście udzielaną. W pierwszej fazie badania uczestników (studentów I roku edukacji zdrowotnej) informowano, że za udział

${ }^{26}$ R.F. Baumeister, Zwierzę kulturowe. Między naturą a kultura, Warszawa 2011. 
w prostym ćwiczeniu fizycznym, tak zwanym „krzesełku”, mogą zarobić określoną kwotę, to jest 2 zł za każde 10 sekund uczestnictwa w zadaniu. Pomocnik eksperymentatora mierzył czas, a następnie informował osobę badaną o wygranej kwocie. Zarobione pieniądze uczestnicy mogli według uznania przypisać: (1) sobie, (2) osobie bliskiej lub (3) wskazanej organizacji pożytku publicznego.

W drugiej fazie, to jest po tygodniu od momentu kontroli zachowań altruistycznych (dzielenia się zarobionymi pieniędzmi), tych samych uczestników proszono o uzupełnienie kwestionariusza na temat deklarowanych postaw wobec niesienia pomocy innym. Przykładowe pozycje narzędzia wyglądały następująco: "Jeżeli mam okazję to staram się pomagać innym”, „Finansowe wspieranie instytucji charytatywnych jest godne pochwały". Wskazane twierdzenia były oceniane na skali od 1 (zdecydowanie nie zgadzam się) do 6 (zdecydowanie zgadzam się).

Osoby badane średnio zarabiały 19,85 zł, przy czym sobie przypisywały 19,15 zł, osobom bliskim oddawały 69 groszy, a organizacjom - zero zł. Z drugiej strony, ci sami uczestnicy deklarowali wysoką gotowość niesienia pomocy innym (średnia ocena twierdzenia: „Jeśli mam okazję, to staram się pomagać innym", wyniosła 5,31) i podkreślali, że wspieranie instytucji charytatywnych jest szczytnym działaniem (średnia ocena twierdzenia "Finansowe wspieranie instytucji charytatywnych jest godne pochwały" wyniosła 5,38), przekazując kilka dni wcześniej aż zero zł na ich działanie.

Wnikliwy Czytelnik może podać alternatywną interpretację uzyskanych wyników. Ludzie mogą zgadzać się ze stwierdzeniem, że wspieranie instytucji charytatywnych jest godne pochwały i jednocześnie tego nie robić, na przykład ze względu na brak wystarczających środków. W tym świetle dyskutowany rezultat świadczyłby o istnieniu wyraźnej rozbieżności między oceną , ,ja" respondentów a oceną powinności wobec innych. Sęk w tym, że uczestnicy dysponowali - skromnymi, ale jednak - środkami finansowymi, które mogli przypisać wybranej organizacji pożytku publicznego. Dowolna kwota wyniosła jednak zero zł. Wynika z tego, że jeżeli chcemy gromadzić wiarygodne dane na temat zachowań ludzi, to nie powinniśmy pytać o nie, ale raczej obserwować ludzi w różnych sytuacjach, w przeciągu dłuższego czasu' ${ }^{27}$.

Jedynym rozsądnym wyjątkiem jest sytuacja, kiedy interesującymi badacza zachowaniami są deklaracje, to jest reakcje respondentów na zadawane im pytania. Nie powinniśmy ich jednak mylić lub utożsamiać z zachowaniami traktowanymi jako rzeczywiste przejawy analizowanych postaw/przekonań osób badanych. Dlaczego? Warto przypomnieć - wysoka akceptacja twier-

${ }^{27}$ L. Jussim, Social perception and social Reality: Why accuracy dominates bias and self-fulfilling prophecy, New York 2012. 
dzenia (a tym samym poprawa mniemania o sobie ${ }^{28}$ ) - „Jeśli mam okazję, to staram się pomagać innym", kosztowała uczestników eksperymentu średnio 69 groszy. Celem badań naukowych nie jest jednak terapeutyzowanie respondentów w przystępnej cenie, ale sensowne wnioskowanie o analizowanych zjawiskach na podstawie wiarygodnych danych empirycznych.

\section{Wybrane osobowe przyczyny niskiej jakości danych jakościowych pochodzących z wywiadu}

Istnieje grupa czynników wpływających negatywnie na wiarygodność danych jakościowych gromadzonych za pomocą wywiadu. Do najistotniejszych można zaliczyć: (1) celowe kłamstwa, (2) luki w pamięci i fałszywe wspomnienia, (3) zniekształcenia interpretacyjne wynikające z posiadanych przekonań, (4) niska motywacja, zmęczenie, i szerzej - zły stan psychofizyczny respondentów oraz (5) sposób prowadzenia rozmowy, zwłaszcza korzystanie z pytań tendencyjnych.

\section{Celowe kłamstwa}

Respondenci mogą oszukiwać, zwłaszcza kiedy są pytani o sprawy niewygodne, na przykład drażliwe, zawstydzające, intymne i tym podobne. Krótko mówiąc, pewne tematy są nasycone czynnikiem aprobaty społecznej. Pytania w rodzaju: „Czy zdradza Pani męża?”, ,Czy zdradzasz innym tajemnice powierzone Ci przez przyjaciół?” i tym podobne mogą wzbudzać lęk przed oceną i/lub tendencję do pozytywnej autoprezentacji ${ }^{29}$. Stąd, respondenci obawiając się negatywnej oceny ze strony innych, mogą rozmijać się z prawdą lub świadomie ją zatajać.

Chcąc dotrzeć do danych drażliwych, badacz nie powinien o nie pytać wprost, ale raczej rozmawiać o nich w zakamuflowany sposób, na przykład korzystając z tak zwanych pytań projekcyjnych lub hipotetycznych ${ }^{30}$. Na przykład, zamiast zapytać: „Czy nadużywasz alkoholu”, można w trakcie rozmowy użyć następującego wstępu: „Czasami ludzie piją alkohol, np. w towarzystwie podczas imprez, i zaczynają zachowywać się w charakterystyczny sposób, np. plącze im się język, mają zwolnione ruchy, mówią głośniej niż zwykle. Kiedy ostatnio zdarzyło Ci się doświadczyć takiego stanu? Jak czę-

${ }^{28}$ M. Kofta, T. Szuster, Złudzenia, które pozwalają żyć, Warszawa 2009.

29 Społeczny kontekst badań psychologicznych i pedagogicznych: wybór tekstów, red. J.M. Brzeziński, J. Siuta, Poznań 1991.

${ }^{30}$ D. Ustjan, Instrumenty konwersacyjne. Rozróżnienia, klasyfikacje i badania, [w:] Wywiad psychologiczny, tom 2 - Wywiad jako spotkanie z człowiekiem, red. K. Stemplewska-Żakowicz, K. Krejtz, Warszawa 2009, s. 131-151; D. Ustjan, Pytania i inne instrumenty konwersacyjne. Zastosowania praktyczne podczas wywiadu diagnostycznego, [w:] Tamże, s. 132-187. 
sto, w ciągu ostatniego tygodnia/miesiąca/roku zdarzyło Ci się doświadczyć takiego stanu?".

\section{Luki w pamięci i fałszywe wspomnienia}

Oprócz intencjonalnego oszukiwania, respondenci opisując zdarzenia z własnego życia, mogą nieświadomie mijać się z prawdą. Pamięć autobiograficzna - to jest ta część pamięci, która specyficznie odnosi się do faktów, zdarzeń i doświadczeń z życia osób, na przykład zatrucia majonezem podczas wesela ukochanej cioci, lotu balonem $z$ rodzicami i tym podobnych ${ }^{31}$ - jest procesem twórczym i selektywnym. Niektóre informacje są z niej usuwane, na przykład w wyniku amnezji dziecięcej lub dysocjacyjnej, inne dodawane, mimo braku związku z rzeczywistymi doświadczeniami jednostek. Wynika z tego, że część znajdujących się w pamięci autobiograficznej danych, o które można zapytać, to konfabulacje, czyli fałszywe wspomnienia zdarzeń z życia badanej osoby.

Okazuje się, że około $20-30 \%$ respondentów jest podatnych na tworzenie realistycznych, choć w rzeczywistości niezwiązanych z doświadczeniami życiowymi konfabulacji. Na przykład, czy przypominasz sobie, jak w dzieciństwie upadłeś/-aś i boleśnie stłukłeś/-aś kolano? Tak? A, czy jesteś pewny/-a, że faktycznie zdarzenie to przytrafiło się Tobie, a nie rodzeństwu lub bliskiej koleżance/koledze? Ludzie mają dużą trudność w rozpoznawaniu, które zdarzenia autobiograficzne rzeczywiście wystąpiły w ich życiu, a które zostały twórczo wymyślone na potrzeby opowiadanej w danej chwili historii życia (narracji).

W spektakularnym eksperymencie Elizabeth Loftus i Jacqueline Pickrell ${ }^{32}$ uczestnikom prezentowano cztery realistyczne historyjki $\mathrm{z}$ ich wczesnego dzieciństwa (4-6. rok życia). Trzy z nich były prawdziwe, jedna fałszywa. Historia fałszywa dotyczyła rzekomego zagubienia się w hipermarkecie, płaczu dziecka, gwałtownego poszukiwania rodziców i happy endu, to jest odnalezienia. Osoby badane proszono o możliwie wierne odtworzenie w pamięci wszystkich historii oraz ich wizualizację, o ile uczestnik miał trudność z przypomnieniem sobie zdarzenia.

Po dwóch tygodniach wracano do osób badanych i ponownie proszono o wydobycie z pamięci czterech zdarzeń, a następnie o ich opisanie. Okazało się, że około 30\% uczestników przypominało sobie fałszywe wspomnienie. Krótko mówiąc, za pomocą prostej manipulacji badanym udało się „wszczepić” (!) obce wspomnienia, tak zwany „implant pamięci”. Jedna uczestniczka opisała „implant” następująco:

31 T. Maruszewski, Pamięć autobiograficzna, Sopot 2005.

${ }^{32}$ E.F. Loftus, J.E. Pickrell, The formation of false memories, Psychiatric Annales, 1995, 25, s. $720-725$. 
widze je mgliście... w znaczeniu takim, że jest ono niewyraźne. Pamiętam kobietę, która mi pomaga i Tima (brata) z mama, robiących coś. Ale nie pamiętam płaczu (...). Pamiętam, że byłam z tą panią i pamiętam zakupy ${ }^{33}$.

W innym, równie intrygującym, eksperymencie ${ }^{34}$ uczestnikom prezento- $^{-}$ wano cztery zdjęcia z dzieciństwa, a następnie proszono o przypomnienie sobie uwiecznionych zdarzeń i możliwie dokładne ich opisanie. Jedno zdjęcie było spreparowane i dotyczyło lotu balonem, wydarzenia, które nigdy nie miało miejsca w życiu badanych osób. Następnie, w odstępach tygodniowych, z uczestnikami przeprowadzano trzy wywiady pogłębione na temat przedstawionego na zdjęciu zdarzenia.

Okazało się, że w ostatnim wywiadzie, w wyniku aktywnego „wydobywania z pamięci" fikcyjnego zdarzenia, aż 50\% (!) uczestników deklarowało, że pamięta lot balonem. Jeden uczestnik opisał doświadczenie następująco:

jestem całkiem pewny, że miało to miejsce, gdy byłem w VI klasie. Hmm w zasadzie za 10 dolarów można było polecieć balonem do góry na ok. 20 metrów. To mogło być w sobotę, i myślę, że poszliśmy z rodzicami, tak, rodzicami i... nie, nie było tam mojej babci (...). Jestem catkiem pewny, że mama stała na dole i zrobiła nam zdjeccie $e^{35}$.

Podczas odpowiednio prowadzonych wywiadów respondenci są w stanie wydobyć z pamięci właściwie wszystko - nawet bardzo bolesne, choć w rzeczywistości fikcyjne doświadczenia. Interesujących przykładów dostarczają wyniki badań nad tak zwanym ruchem odzyskiwania pamięci ${ }^{36}$, dynamicznie rozwijanym w 80 . latach $\mathrm{XX}$ wieku. Za pomocą tak zwanego wywiadu poznawczego $^{37}$, analityczni terapeuci pomagali klientom wydobywać/rekonstruować rzekomo wyparte z pamięci traumatyczne zdarzenia - zwłaszcza kazirodcze gwałty doświadczane w okresie dzieciństwa.

Elizabeth Loftus ${ }^{38}$ (1997) przytacza historię Beth Rutherford - kobiety, która w wyniku aktywnego rekonstruowania wspomnień (w rzeczywistości: wszczepiania fałszywych wspomnień) przypomniała sobie, że jej ojciec

33 Tamże, s. 723.

${ }^{34}$ K.A. Wade i in., A picture is worth a thousand lies: Using false photographs to create false childhood memories. Psychonomic Bulletin and Review, 2002, 9, s. 597-603.

${ }_{35}$ Tamże, s. 600.

${ }^{36}$ E. Aronson, C. Travis, Btadza wszyscy (ale nie ja), Sopot - Warszawa 2008.

${ }^{37}$ To jest wywiadu, w trakcie którego badacz steruje uwagą respondenta, kierując ją na drobne detale zdarzenia i jego kontekst. Ponadto, zachęca osobę badaną do opisywania zdarzeń z różnych punktów widzenia, wielokrotnego odtwarzania ich w wyobraźni. W ten sposób, „nieprawda" powtarzana wielokrotnie, przekształcana jest w pamięci autobiograficznej w „mglistą prawdę", "prawdę prawie wyraźną i na wyciągnięcie ręki” i koniec końców - „prawdę subiektywnie prawdziwą".

38 E.F. Loftus, Creating false memories, Scientific American, 1997, 277, s. 70-75. 
- pastor - wraz z jej matką, regularnie przez siedem lat (od 7. do 14. roku życia) gwałcił ją. Podczas terapii Beth rozwinęła wspomnienie dwukrotnego zajścia w ciążę z ojcem oraz aborcji dokonanej za pomocą wieszaka (sic!). Sąd uznał winę rodziców, posyłając ich na wiele lat do więzienia. Ponadto, „pokrzywdzona" za poniesione straty moralne otrzymała $1 \mathrm{mln}$ \$ odszkodowania.

Najbardziej narażone na generowanie fałszywych wspomnień są osoby podatne na wpływ sugestii, o bujnej, plastycznej wyobraźni. Stąd, bardzo często konfabulować mogą dzieci, myląc wspomnienia dotyczące rzeczywistych zdarzeń z fikcyjnymi. Ponadto, najłatwiej wszczepić wspomnienia pochodzące od osób bliskich, ważnych i podobnych do nas, na przykład krewnych, oraz wspomnienia związane z relacjami rodzinnymi i rówieśniczymi (co jest szczególnie wyraziste u bliźniąt, których biografie mogą się silnie przenikać i uzupełniać. $W$ takich warunkach, po pewnym czasie, bliźniakom trudno odróżnić, które wydarzenie jest ich doświadczeniem, a które - rodzeństwa). Implanty pamięci muszą być również prawdopodobne. Wmówienie osobie posiadającej obie nogi, że w dzieciństwie prawą straciła w paszczy rekina, wydaje się całkowicie niemożliwe.

\section{Zniekształcenia interpretacyjne wynikające z posiadanych przekonań}

Przekonania na temat świata fizycznego i społecznego, na przykład cech przedstawicieli różnych grup społecznych, rasowych, wiekowych i tym podobnych, mogą być źródłem uprzedzeń lub nieadekwatnych - zbyt wysokich lub zbyt niskich - oczekiwań ${ }^{39}$.

W związku z tym, oceny tego samego obiektu (zdarzeń, zachowań ludzi), wydawane przez dwóch niezależnych obserwatorów o odmiennych poglądach, mogą się radykalnie różnić. Na przykład, bicie osób czarnoskórych po twarzy, w pewnych kręgach jest oceniane jako przejaw bohaterstwa w walce o lepszą ojczyznę, natomiast w innych - ludzkiej podłości i barbarzyństwa ${ }^{40}$.

\section{Niska motywacja/zły stan psychofizyczny uczestników badania}

Osoby badane mogą nie odczuwać potrzeby rzetelnego odpowiadania na pytania wywiadu. Niska motywacja jest szczególnie prawdopodobna, kiedy stosunek respondentów wobec badacza lub problematyki wywiadu jest negatywny, na przykład gdy respondenci są zmuszani do udziału w badaniu lub kiedy budowa zadawanych pytań jest nieprawidłowa.

${ }^{39}$ Efekty oczekiwań interpersonalnych. Wybór tekstów, red. S. Trusz, Warszawa 2013; Intrapersonal and interpersonal expectancies, red. S. Trusz, P. Bąbel, London 2016.

${ }^{40}$ T.D. Nelson, Handbook of prejudice, stereotyping, and discrimination, New York 2009; B.E. Whitley, M.E. Kite, The psychology of prejudice and discrimination, Belmont 2010. 
Błędy konstrukcyjne mogą dotyczyć na przykład podwójnych, a nawet wielokrotnych przeczeń $\mathrm{w}$ treści wypowiedzi kierowanych wobec osób badanych („Nigdy nie sądziłem, że to mogłoby się nie zdarzyć”), wypowiedzi zbyt długich („Moi nauczyciele często powtarzali w trakcie zajęć, że podział obowiązków domowych na typowo męskie, np. naprawa samochodu lub praca w kopalni, i typowo kobiece, np. przygotowywanie posiłków lub karmienie dzieci, jest naturalny i należy go zaakceptować, nawet jeśli w społeczeństwie dominują wartości egalitarne"). Tego rodzaju stwierdzenia (zwłaszcza kiedy jest ich dużo) mogą zniechęcać lub irytować respondentów. Wzrasta wówczas szansa uzyskiwania odpowiedzi płytkich, zdawkowych, wymijających i tym podobnych.

Ponadto, źródłem niskiej jakości materiału empirycznego może być zły stan psychofizyczny respondentów. Zbyt długie lub zawiłe punkty wywiadu mogą zniechęcać do przemyślanego, spójnego i pogłębionego wypowiadania się na określone tematy. W związku z tym, wywiady warto prowadzić z respondentami wypoczętymi i zainteresowanymi poruszaną $\mathrm{w}$ badaniu problematyką.

\section{Sposób prowadzenia rozmowy - pytania tendencyjne}

Źródłem niskiej jakości odpowiedzi respondentów mogą być nieodpowiednio zadawane pytania.

Przykład 1. Na pytanie o to, „,czy w dalszym ciągu nadużywasz alkoholu?", osoba badana nie jest w stanie odpowiedzieć: ,jak dotąd nie miałem/-am jakichkolwiek problemów z alkoholem". Odpowiedź przecząca wskazuje, że rozmówca w przeszłości nadużywał alkoholu, natomiast twierdząca, że nadal systematycznie pije. Winne temu są tak zwane pytania tendencyjne (alternatywne i sugerujące/naprowadzające), których badacz powinien unikać $\mathrm{w}$ trakcie rozmowy z uczestnikami wywiadu.

Przykład 2. W eksperymencie Elizabeth Loftus i Johna Palmera ${ }^{41}$ uczestnikom prezentowano film, na którym zarejestrowano wypadek samochodowy, a następnie część osób pytano o to, „Jak szybko jechały samochody, gdy roztrzaskały się o siebie". Pozostałych pytano o to, "Jak szybko jechały samochody, gdy doszło do kolizji" (lub stłuczki, zderzenia i kontaktu - w zależności od warunku). Drobna manipulacja treścią pytania wpłynęła znacząco na oszacowania prędkości jazdy samochodów - roztrzaskane samochody, zdaniem uczestników, poruszały się ze średnią prędkością 40,5 km/h. Średnie ocen osób z warunku „kolizji”, ,stłuczki”, ,zderzenia” i „,kontaktu” były niższe i wyniosły odpowiednio: 39,$3 ; 38,1 ; 34,0$ i $31,8 \mathrm{~km} / \mathrm{h}$.

${ }^{41}$ E.F. Loftus, J.C. Palmer, Reconstruction of automobile destruction: An example of the interaction between language and memory, Journal of Verbal Learning and Verbal Behavior, 1974, 13, s. 585-589. 
Ludzie myślą za pomocą języka, dlatego to, jakich słów używamy podczas wywiadu może wpływać na reakcje werbalne respondentów. Warto podkreślić - $\mathrm{w}$ eksperymencie Loftus i Palmera ${ }^{42}$ uczestnicy nie kłamali - odpowiadali zgodnie z przekonaniami dotyczącymi prędkości obserwowanych pojazdów. Różnice ocen zostały narzucone poprzez wzbudzenie odmiennych schematów poznawczych, związanych z terminem "roztrzaskać” vs „zderzyć", ,zetknąć" i tym podobne.

Podsumowując, każdy z omówionych czynników, to jest: (1) celowe oszukiwanie; (2) fałszywe wspomnienia i konfabulacje; (3) tendencyjne interpretacje wynikające z posiadanych poglądów; (4) niska motywacja lub zły stan psychofizyczny respondentów oraz (5) korzystanie z pytań tendencyjnych, wpływa negatywnie na jakość gromadzonego podczas wywiadu materiału empirycznego, godząc w rzetelność (precyzję) i trafność (sensowność) proponowanych interpretacji, a w konsekwencji - formułowanych przez badacza wniosków.

\section{W jaki sposób dbać o jakość danych jakościowych - wnioski praktyczne}

Z myślą o wysokiej jakości danych jakościowych, gromadzonych za pomocą metod/strategii obserwacji i wywiadu, osobom przygotowującym badania warto polecić następujące procedury lub reguły: (1) dbałości o tak zwaną trafność wewnętrzną badania, (2) triangulacji źródeł danych, metod i badaczy oraz (3) życzliwego sceptycyzmu.

\section{Trafność wewnętrzna badania}

Dbałość o trafność wewnętrzną badania jakościowego wiąże się z przestrzeganiem reguły dominacji przedmiotu badania nad metodą. Zgodnie z nią, sposób gromadzenia i opracowywania danych empirycznych powinien być dopasowywany do treści analizowanych zjawisk.

W związku z tym, w przypadku zewnętrznych (obserwowalnych) zachowań werbalnych i niewerbalnych, na przykład pocałunków i tempa mówienia - traktowanych jako przejawy, odpowiednio: zakochania i zdenerwowania, bardziej optymalną metodą gromadzenia danych jest obserwacja niż wywiad. Dla odmiany, jeżeli przedmiotem badania są zjawiska trudno uchwytne, wykraczające poza możliwość bezpośredniego obserwowania, na przykład myśli, osobowość i tym podobne, lub też o zjawisku, na przykład niskiej samoocenie, można wnioskować z wypowiedzi badanych jednostek,

42 Tamże. 
typu: „jestem nikim... do niczego się nie nadaję...” i tym podobne, właściwszą metodą gromadzenia danych wydaje się wywiad niż obserwacja ${ }^{43}$.

Równie ważnym kryterium doboru metody jest cel prowadzonych badań. Analiza relacji przyczynowo-skutkowych (wyjaśnianie i przewidywanie zjawisk) jest możliwa, o ile badacz korzysta z metody eksperymentu. Na przykład, ustalając stopień, $\mathrm{w}$ jakim poczucie sprawstwa wpływa na samoocenę osób, badacz może manipulować poziomem spostrzeganej kontroli nad przebiegiem zdarzeń, a następnie sprawdzać, czy utrata lub nie kontroli istotnie wpływa na poziom samooceny badanych jednostek.

Dla odmiany, ocena współwystępowania zjawisk (korelacji między zmiennymi), bez określania kierunku zależności, jest możliwa, gdy badacz korzysta z metody eksperymentu, sondażu i obserwacji. Na przykład, analizując związek między otwartością na doświadczenie a czasem poświęcanym na lekturę książek podróżniczych, badacz może oceniać obie zmienne za pomocą kwestionariuszy, na przykład osobowości i oceny czasu spędzanego na czytaniu książek, lub mierząc czas poświęcany przez osoby na ulubione aktywności. W pierwszym przypadku badacz korzystałby z metody sondażu, natomiast $\mathrm{w}$ drugim - z obserwacji.

Na koniec, właściwy dla badań jakościowych opis gęsty analizowanych zjawisk jest możliwy, kiedy badacz dysponuje danymi gromadzonymi za pomocą niestandaryzowanej obserwacji uczestniczącej lub wywiadu swobodnego, ale nie obserwacji/wywiadu standaryzowanego lub eksperymentu. $\mathrm{Na}$ przykład, analizując motywy sięgania po używki przez studentów, badacz może o nie zapytać, na przykład podczas wywiadu, lub zaobserwować, w jakich okolicznościach, w towarzystwie jakich emocji badana osoba sięga po papierosa, alkohol lub inny narkotyk.

Podsumowując, dobór właściwej metody badań jest kluczowy z punktu widzenia oceny wiarygodności gromadzonych danych empirycznych. Metody nieadekwatne (niedopasowane do przedmiotu badań), w porównaniu z adekwatnymi, są źródłem informacji o niższej jakości. Cios w szczękę osoby czarnoskórej jest trafniejszym i rzetelniejszym przejawem rasizmu, niż deklaracja miłości i przyjaźni wyrażona przez łysogłowego sprawcę wobec odmienności rasowych. Krótko mówiąc: dane gromadzone na podstawie bezpośredniej obserwacji, w porównaniu z informacjami pochodzącymi z samoopisów, są zazwyczaj bardziej wiarygodne (zatem: obserwacja > wywiad).

Z drugiej jednak strony, ludzie mogą zachowywać się nieautentycznie, na przykład wiedząc, że są obserwowani, natomiast wypowiadać się szczerze na różne tematy podczas wywiadu (zatem: wywiad > obserwacja). Rzecz jasna,

${ }^{43}$ A.N. Oppenheim, Kwestionariusze, wywiady; K. Stemplewska-Żakowicz, Metoda wywiadu w psychologii, [w:] Wywiad psychologiczny, tom 1 - Wywiad jako postępowanie badawcze, s. 31-89. 
osoba badana może „wydawać się" prawdomówna, choć w rzeczywistości zręcznie manipulować informacjami, na przykład przedstawiając siebie w jak najlepszym świetle lub zapominając o pewnych zdarzeniach (zatem: obserwacja > sondaż).

\section{Triangulacja źródeł danych, metod i badaczy}

Rzetelność i trafność danych jakościowych oraz wykonywanych na ich podstawie analiz można ocenić, korzystając z procedury triangulacji (zestawiania, porównywania), a w jej ramach: (1) triangulacji źródeł danych. Analizując określone zjawisko, na przykład przemocy domowej, badacz może analizować zachowania małżonków, pytając o nie wyłącznie żony, wyłącznie męża, żony i męża lub też żony, męża, sąsiadów i dzieci. Wnioski wyprowadzane z przesłanek pochodzących z różnych źródeł (np.: żony, męża, sąsiadów i dzieci) są zazwyczaj bardziej wiarygodne, niż wnioski formułowane wyłącznie na podstawie informacji czerpanych $\mathrm{z}$ jednego (być może tendencyjnego/uprzedzonego) źródła. Podobieństwo informacji pochodzących z różnych źródeł (np. żony i dziecka) świadczy o ich wiarygodności. Opisy formułowane na podstawie wiarygodnych danych, ich interpretacja i w konsekwencji - tworzona teoria, charakteryzują się wyższą rzetelnością (precyzją) i trafnością (sensownością), w porównaniu z takimi, których źródłem są niewiarygodne dane. (2) triangulacja metod. Badacz może opisywać lub interpretować zjawiska, korzystając z danych pochodzących wyłącznie z wywiadu, wyłącznie z obserwacji albo obu metod naraz. Na przykład, analizując okoliczności, w których ludzie najczęściej i najchętniej kłamią, można ich o to zapytać lub też obserwować w różnych sytuacjach, zadając od czasu do czasu pytania na temat wybranych szczegółów. Wiarygodne wnioski na temat badanego zjawiska można formułować, korzystając z danych gromadzonych za pomocą więcej niż jednej metody (ludziom trudniej jest komunikować nieprawdę za pośrednictwem kilku niezależnych kanałów, np. słów i mowy ciała) ${ }^{44}$. (3) triangulacja badaczy. Dane jakościowe mogą być gromadzone, a następnie niezależnie opracowywane przez kilku badaczy. Warto podkreślić, że wraz ze wzrostem poziomu zgodności treści parafraz, kategoryzacji i kodowania materiału tekstowego kilku niezależnych badaczy, wzrasta poziom rzetelności i trafności proponowanych opisów oraz interpretacji.

\section{Sceptycyzm}

Ludzie są podatni na różnego rodzaju zniekształcenia i ograniczenia poznawcze. Na przykład, uczestnicy wywiadu charakteryzują się zdolnością do

${ }^{44}$ E. Babad, F. Bernieri, R. Rosenthal, Nonverbal communication and leakage in the behavior of biased and unbiased, Journal of Personality and Social Psychology, 2003, 56, s. 89-94. 
tworzenia fałszywych wspomnień. Z drugiej strony, obserwatorzy z powodu, na przykład zjawiska ślepoty okołozmianowej, mogą tendencyjnie rejestrować, zapamiętywać, a następnie wydobywać z pamięci określone informacje, pomijając inne, ważne z punktu widzenia analizowanej problematyki.

Ponadto, badacz może w swoisty dla siebie sposób interpretować wypowiedzi i zachowania badanych osób, świadomie lub nieświadomie korzystając z posiadanych schematów poznawczych, na przykład stereotypu mądrego vs głupiego ucznia, pracowitego vs leniwego pracownika, odpowiedzialnego vs agresywnego „eurosieroty” i tym podobnych. W związku z tym, badacz podczas analizowania zgromadzonego materiału, a następnie formułowania wniosków na temat analizowanych zjawisk, powinien zachowywać życzliwy dystans wobec siebie i własnych zdolności analityczno-interpretacyjnych oraz danych pochodzących z różnych źródeł, pamiętając o właściwych dla ludzi ograniczeniach poznawczych, osobowościowych i tym podobnych.

\section{BIBLIOGRAFIA}

Anderson-Levitt K.T., Etnography, [w:] Handbook of complementary methods in education research, red. J.L. Green, G. Camilli, P.B. Elmore, Lawrence Erlbaum Associates, Publishers, Mahwah 2006.

Aronson E., Travis C., Błądza wszyscy (ale nie ja), Wydawnictwo Smak Słowa, Sopot - Warszawa 2008.

Babad E., Bernieri F., Rosenthal R., Nonverbal communication and leakage in the behavior of biased and unbiased, Journal of Personality and Social Psychology, 2003, 56.

Baumeister R.F., Zwierze kulturowe. Między natura a kultura, Wydawnictwo Naukowe PWN, Warszawa 2011.

Baumgarten M., Paradigm wars - validity and reliability in qualitative research, GRIN Verlag, Auflage 2010.

Brzeziński J.M., Badania eksperymentalne w psychologii i pedagogice, Wydawnictwo Naukowe Scholar, Warszawa 2008.

Brzeziński J.M., Metodologia badań psychologicznych, Wydawnictwo Naukowe PWN, Warszawa 2012.

Chabris C., Simons D., Niewidzialny goryl. Dlaczego intuicja nas zawodzi? Wydawnictwo Laurum, Warszawa 2011.

Darley J.M., Fazio R.H., Proces potwierdzania oczekiwań w sekwencji interakcji społecznych, [w:] Efekty oczekiwań interpersonalnych. Wybór tekstów, red. S. Trusz, Wydawnictwo Naukowe Scholar, Warszawa 2013.

Doliński D., Psychologia wpływu społecznego, Wydawnictwo Naukowe Scholar, Warszawa 2008.

Dunbar R., Kłopoty z nauka, Oficyna Wydawnicza Volumen, Warszawa 1996.

Efekty oczekiwań interpersonalnych. Wybór tekstów, red. S. Trusz, Wydawnictwo Naukowe Scholar, Warszawa 2013.

Fiske S.T., Taylor S.E., Social cognition. From brain to culture, McGraw Hill Higher, Boston 2009. 
Flick U., Jakość w badaniach jakościowych, Wydawnictwo Naukowe PWN, Warszawa 2011.

Geertz C., Opis gęsty - w stronę interpretatywnej teorii kultury, [w:] Badanie kultury. Elementy teorii antropologicznej, red. M. Kempny, E. Nowicka, Wydawnictwo Uniwersytetu Jagiellońskiego, Kraków 2003.

Glass G.V., Meta-analysis: The quantitative synthesis of research findings, [w:] Handbook of complementary methods in education research, red. J.L. Green, G. Camilli, P.B. Elmore, Lawrence Erlbaum Associates, Publishers, Mahwah 2006.

Hammersley M., Atkinson P., Metody badań terenowych, Zysk i S-ka Wydawnictwo, Poznań 2000.

Hofmann W., Gawronski B., Gschwendner T., Le H., Schmitt M., A meta-analysis on the correlation between the Implicit Association Test and explicit self-report measures, Personality and Social Psychology Bulletin, 2005, 31.

Intrapersonal and interpersonal expectancies, red. S. Trusz, P. Bąbel, Routledge, London 2016.

Jussim J., Social perception and social reality: Why accuracy dominates bias and self-fulfilling prophecy, Oxford University Press, New York 2012.

Kirk J., Miller M.L., Reliability and validity in qualitative research, SAGE Publication, Newbury Park 1986.

Kofta M., Szuster T., Złudzenia, które pozwalają żyć, Wydawnictwo Naukowe PWN, Warszawa 2009.

Konecki K., Studia z metodologii badań jakościowych: teoria ugruntowana, Wydawnictwo Naukowe PWN, Warszawa 2000.

Kvale S., InterViews. Wprowadzenie do jakościowego wywiadu badawczego, Trans Humana, Białystok 2004.

Kvale S., Prowadzenie wywiadów, Wydawnictwo Naukowe PWN, Warszawa 2010.

Lichtman M., Qualitative research in education. A user's guide (2nd edition), SAGE Publications, London 2013.

Lofland J., Snow D.A., Anderson L., Lofland L.H., Analiza układów społecznych. Przewodnik metodologiczny po badaniach jakościowych, Wydawnictwo Naukowe Scholar, Warszawa 2009.

Loftus E.F., Creating false memories, Scientific American, 1997, 277.

Loftus E.F., Palmer J.C., Reconstruction of automobile destruction: An example of the interaction between language and memory, Journal of Verbal Learning and Verbal Behavior, 1974, 13.

Loftus E.F., Pickrell J.E., The formation of false memories, Psychiatric Annales, 1995, 25.

Maruszewski T., Pamięć autobiograficzna, Gdańskie Wydawnictwo Psychologiczne, Sopot 2005.

Nauberg S.L., Proces potwierdzania oczekiwań w interakcjach obciażonych stereotypami, [w:] Efekty oczekiwań interpersonalnych. Wybór tekstów, red. S. Trusz, Wydawnictwo Naukowe Scholar, Warszawa 2013.

Nelson T.D., Handbook of prejudice, stereotyping, and discrimination, Psychological Press, New York 2009.

Nestor P.G., Schutt R.K., Research methods in psychology. Investigating human behavior, SAGE Publication, Los Angeles 2012.

Oppenheim A.N., Kwestionariusze, wywiady, pomiary postaw, Wydawnictwo Prószyński i S-ka, Warszawa 2004.

Rubin H.J., Rubin I.S., Qualitative interviewing. The art of hearing data (3rd edition), SAGE Publication, Los Angeles 2012.

Schoenfeld A.H., Design experiments, [w:] Handbook of complementary methods in education research, red. J.L. Green, G. Camilli, P.B. Elmore, Lawrence Erlbaum Associates, Publishers, Mahwah 2006. 
Społeczny kontekst badań psychologicznych i pedagogicznych: wybór tekstów, red. J.M. Brzeziński, J. Siuta, Wydawnictwo Naukowe UAM, Poznań 1991.

Stemplewska-Żakowicz K., Metoda wywiadu w psychologii, [w:] Wywiad psychologiczny, tom 1 - Wywiad jako postepowanie badawcze, red. K. Stemplewska-Żakowicz, K. Krejtz, Pracownia Testów Psychologicznych, Warszawa 2009.

Ustjan D., Instrumenty konwersacyjne. Rozróżnienia, klasyfikacje i badania, [w:] Wywiad psychologiczny, tom 2 - Wywiad jako spotkanie z człowiekiem, red. K. Stemplewska-Żakowicz, K. Krejtz, Pracownia Testów Psychologicznych, Warszawa 2009.

Ustjan D., Pytania i inne instrumenty konwersacyjne. Zastosowania praktyczne podczas wywiadu diagnostycznego, [w:] Wywiad psychologiczny, tom 2 - Wywiad jako spotkanie z człowiekiem, red. K. Stemplewska-Żakowicz, K. Krejtz, Pracownia Testów Psychologicznych, Warszawa 2009.

Wade K.A., Garry M., Read J.D., Lindsay D.S., A picture is worth a thousand lies: Using false photographs to create false childhood memories, Psychonomic Bulletin and Review, 2002, 9.

Weathington B.L., Cunningham C.J., Pittenger D.J., Research methods for the behavioral and social sciences, John Wiley \& Sons, New Jersey 2010.

Whitley B.E., Kite M.E., The psychology of prejudice and discrimination, Wadsworth, Belmont 2010.

Wojciszke B., Dane i pseudodane w procesie spostrzegania ludzi, [w:] Złudzenia, które pozwalaja żyć, red. M. Kofta, T. Szutrowa, Wydawnictwo Naukowe PWN, Warszawa 2009. 